\title{
Kamila Zelga*
}

\section{KEY PERFORMANCE INDICATOR AS A TYPE OF PERFOR- MANCE MEASUREMENT - ANALYSIS OF A CHOSEN ENTERPRISE}

\begin{abstract}
A b s t r a c t: Key Performance Indicators are key business metrics used by organizations in the processes of evaluating and measuring the extent to which the objectives have been achieved. KPIs positively affect the effectiveness of tasks performed by employees, which determines the level of remuneration they receive. The article shows the essence and the way of implementing the KPI indicators as well as the key challenges faced by the controlling department. Own research has shown that the use of such methodology is supposed to allow the company to develop and employees to undertake increasingly more productive tasks.
\end{abstract}

K e y w o r d s: key performance indicators, motivation, controlling

J E L C 1 a s s if i c at i o n: L21; L22

\section{INTRODUCTION}

Employees are the most important resource of every organization, and their work and commitment necessarily supported by appropriate motivation is the key to the success of a given business. Therefore, the question should be asked how to improve the quality of work, which translates into a considerable progress of both the organization and individual employee goals.

Enhancing the efficiency of work and the involvement of employees in an organization is possible by translating the general policy objectives for specific sub-goals and operations of internal organisational units.

An excellent way to implement the above-mentioned assumptions is to introduce the Key Performance Indicators (KPIs), which the level of bonus granted to the subordinates depends on.

\footnotetext{
Adres do korespondencji: Kamila Zelga, Jan Kochanowski University in Kielce, Faculty of Law, Administration and Management, 25-406 Kielce, ul. Świętokrzyska 21, kamilazelga@wp.p1
} 
The purpose of this article is to show the specificity, the economic legitimacy of implementing the KPIs and the method of calculating them. It is proved that KPIs determine the level of remuneration of employees by motivating them to undertake productive tasks. The challenges faced by the controlling department in the field of monitoring goals oriented on continuous improvement and achieving maximum operational efficiency in a functioning enterprise are also to be described. The analysis is based on the available subject literature and own research on the example of the production and trading company in the Świętokrzyskie province.

\section{KEY PERFORMANCE INDICATORS - THEIR ESSENCE, IMPLEMENTATION, CALCULATION}

Key Performance Indicators - KPIs, are defined as financial and non-financial measures used by the organization in the processes of assessing the progress made on the targets set[Grycuk, 2010, s.28]. KPIs are one of the key tools of Business Performance Management - a set of management and analytic operations that enhances the efficiency of corporate activities as well as the management of an organization's performance[Grycuk, 2010, s.28].

They are of particular importance for building a results-oriented organizational culture, as they provide employees with objective feedback on their work, costs and quality. KPIs enable to check the effectiveness of a given employee, determining the right level of bonus for accomplishing a given goal.

What is more, KPIs are a tool for managerial control that allows to make the right decisions quickly, plan and prioritize various business activities and respond to emerging problems. They also support continuous improvement processes and more efficient use of resources held by the organization.

Key performance indicators can be particular of assistance in reducing a large amount of information to a small number of key data that shows meaningful results reflecting the achievement of the goal. Since KPIs are characteristic for any organization, they may vary depending on the sector of activity, size, specific features or development strategy.

Properly selected KPIs allow to [https://marketingwsieci.pl/slownik-e-marketingu/kpi/\# 01.03.2018].

- target resources on activities that are important in terms of implementation of the assumed strategy,

- prioritise corporate actions appropriately,

- make decisions quickly based on the selected key information.

The implementation of KPIs requires the definition of the mission, vision and strategic goals of the organization, and then the cascading of objectives to lower 
organizational levels, so as to enable the business context of the operation to be realized.

The process of cascading involves delegating the objectives that are inevitably identical to the organization aims to subordinate staff[Kałużna, 2016, s. 41]. In this case the goals of the subordinate, for example manager of the organization, should result from the goals of the supervisor, who poses the question: "What should my subordinate achieve so that I reach my own target?"

It should be noted that the managers receive from the director only those goals that are within their responsibility. The performance of several managers may consist in the implementation of one director's goal. Therefore, each of them is to be responsible for executing only the particular "fragment" of the given objective - the one they are assigned to.

The goal cascaded from the director's level to the manager's level should be detailed so that its scope is reduced to the scope of responsibility of a given manager[Kałużna, 2016, s. 41]. In the case when the target is highly aggregated, it may be helpful to indicate certain tasks supporting the given objective, which in turn can serve as a source of performance goals for subordinates. Due to the scope of the duties and responsibilities of the managers, there may be more performance goals in place of efficiency goals specified in their individual objective sheet.

Setting performance goals is all the more justified when the manager is responsible for the implementation of many tasks, where the execution time is shorter than the period necessary for fulfilling the planned objectives [https:// www.investopedia.com/terms/k/kpi.asp 02.03.2018]. Then it might be a good solution to set the goal related to successful completion (which means well in terms of content and time) of the bonus tasks indicated (the list can be supplemented during the period)[Kałużna, 2016, s. 42]. The meter is then the supervisor's assessment (on a scale of 1 to 5) in terms of the substantive quality and timely execution of the bonus tasks. In order to be able to make a reliable assessment, it is necessary to elaborate and attach to the objective sheet the description of the task being performed, including its substantive scope with division into full-time equivalents, schedule and budget. In this respect, an application of task and operational objectives may be more effective than management using a number of key performance indicators.

In addition to individual goals, the manager's objective sheet may contain common (corporate) or team aims. An example of a corporate goal could be to achieve the operating profit of the entire organization at a certain level. This is so called a solidarity goal, supporting shared responsibility for the company's results. Another example of the common objective is a realization of current tasks of the given department within the set budget to ensure the involvement and cooperation of the whole team towards its achievement. 
Cascading goals therefore helps to introduce a special action plan for achieving the aim, thanks to which the company increases its chances of implementing the strategy and understanding by employees their role and value in the organization[http://www.leanpassion.pl/slownik/kaskadowanie-celow/ 02.03.2018].

It should be mentioned that an impact of individual goals is differentiated by giving them various weightings. Typically, corporate objectives apply to all employees, but they can have different effects on bonuses, governed by the percentage weigh granted. The higher the position in the structure, the greater the impact on the company's performance. In case of managers' sheets, the influence of company goals is generally to be smaller than in their superiors' sheets.

Each chosen operational objective should have an appropriate value, which will be determined by KPIs. In turn each key efficiency indicator is supposed to bear an assigned numerical value that may allow to assess implementation of the given goal [https://marketingwsieci.pl/slownik-e-marketingu/kpi/\# 02.03.2018]. The relevant KPIs should also be embedded within a certain time interval.

Summing up, the manager's sheet is expected to include individual and team goals, with a strong focus on a maximum of 4-5 objectives relating to the most important areas of company activities. In the case of a larger number of goals, their percentage share in the structure will be fragmented. It is assumed that the weight of a single target cannot be lower than 10\% [Kałużna, 2016, s. 42]. Lower weight goals are either so insignificant that they can be omitted, or too detailed that should be defined on a more general level. A certain level of KPI implementation is associated with receiving the appropriate level of bonus for a given goal. A particular weight which determines its value is also assigned to each objective.

\section{MONITORING OF OBJECTIVES IN PROJECT TEAMS - A CHALLENGE FOR THE CONTROLLING DEPARTMENT}

An important task of the controlling department of a given company is to analyze the framework of the budget designed for creating new solutions. Such budgets do not mean financial values, they can be expressed in the value of costs or expenses, but also the number of hours, working days for individual activities, or a set of actions to be performed, with certain safety or risk margins. The controllers are supposed to monitor constantly the work of their project team by providing guidance, combining information, watching the entire project portfolio, and analyzing the whole corporate value chain [Szarska, 2017, s. 22]. The most difficult thing is here to ensure that the way of work and communication from controlling motivates effectively and creates new solutions.

The main directions of modern controlling are[Szarska, 2017, s. 22]:

- determining the level of risk for individual projects,

- risk performance analysis, 
- monitoring and signaling whether and at which moment to withdraw from a given project or from its particular stage,

- assessing how many tests to perform, how many changes to accept and - how this may affect the costs or the expected return on investment.

The further development of monitoring and controlling systems requires a certain level of professional maturity of the teams, trust and reliability, which is possible only when there are good relations between the leader and the employees. This means that the supervisor needs to communicate effectively with his subordinates, devoting time to individual conversations and direct contact with them. Despite all modern communication tools, such personal contact with employees is absolutely necessary. Therefore, it is recommended to eliminate all inefficiencies, automate simple tasks and time-consuming undertakings, and concentrate energy on listening to employees and discussing problems [Szarska, 2017, s. 22].

It is worth mentioning that improper transfer of financial or business information by controllers through complicated and incomprehensible statistics is inevitably connected with waste of managerial time. All that make it really difficult to build good relations between leaders and employees as well as to develop mutual trust and responsibility [Szarska, 2017, s. 23]

However, by applying global reporting standards in accordance with the idea of IBCS (International Business Communication Standards), the time for understanding management information is shortened [Brown, 1996, s. 4]. Visually standardized reports and analyzes make one look at the report enough for the manager to make decisions or draw conclusions for the future. Such an arrangement of work can thus indirectly affect the level of trust in business, because managers are to be given more time for interviews and cooperative work with subordinates.

\section{OBJECTIVE, SUBJECT AND METHODOLOGY OF OWN RESEARCH}

The aim of the research conducted for the purposes of this work is to analyze the KPI index as an important motivational tool at the surveyed production and trading company. The working hypothesis assumes that KPIs are the key performance indicators that support the company's achievement of operational and strategic objectives, as well as affect positively the motivation of employees.

The given aim is to be realized through an empirical questionnaire-based interview. As part of the chosen methodology, the free interview method was used with the HR specialist in the Świętokrzyskie Province, based on the prepared dispositions for the interview. 
The respondent has been employed in the examined organization for 5 years, and currently he holds the position of a deputy HR director.

The interview was conducted at the beginning of February 2018 at the headquarters of the company. The main part of the questionnaire consisted of 10 questions. For the most part, these were open questions asked in a face-to-face conversation, conducted according to the assumed goal and a previously prepared plan. The questions concerned the impact of KPI on the effectiveness of the current incentive system, the implementation of the objectives of the examined enterprise and the explanation of the specificity of calculating the indicator in relation to the employee bonus paid.

The conversation was recorded using a voice recorder, then, after listening to it, appropriate conclusions and observations were formulated. The choice of the company was made in a deliberate way. Not only the size of the company and the complexity of the incentive system were taken into consideration, but also the general need of the management for conducting the analysis and the availability of given materials.

\section{IMPLEMENTATION OF THE KPI INDICATOR ON THE EXAMPLE OF A CHOSEN ENTERPRISE OF THE ŚWIĘTOKRZYSKIE VOIVODESHIP}

The analyzed company is a leading producer and market leader in the field of building materials. The company is a group of production and trade companies dispersed in Europe. The production processes are currently carried out at the premises of three production plants, while the company operates comprehensively in 61 countries.

The wide range of goods offered by the analyzed company proves the production of high quality and functional products that are of the finest design and taste at the same time. However, fully satisfied customers and gradually increasing sales revenues are the best reference of the company's success.

According to the respondent, the KPIs take into account the quantitative targets of the objectives pursued, which are the basis for determining employee bonuses. In the aforementioned methodology, batch input data constituting a kind of a plan to be executed is generated on the basis of the budget approved for a particular year in a given area of the company's activity. As the expert believes, the high level of ambition by an employee can make the bonus for achieving the KPI goals differ from the funds allocated for it, but then in turn the ineffective implementation of such targets may lead to the KPI being placed at a relatively low position.

Below there is an example of the KPI scheme, based on which the amount of the discretionary bonus being a part of the remuneration structure in the analyzed 
organization is calculated. The appropriate percentage of the bonus according to the prescribed multipliers is assigned to the given level of implementation of KPIs.

Example of the KPI structure according to a data map:

- 20\% Rotation of Semi-finished Products

- 20\% Rotation of Finished Goods

- 60\% Sales Profitability - operating margin

Table 1: KPI implementation vs \% of the due bonus

\begin{tabular}{|c|c|c|c|c|c|c|}
\hline \multirow{2}{*}{$\begin{array}{c}\text { Rotation of Semi-fin- } \\
\text { ished Products }\end{array}$} & \multirow{2}{*}{$\begin{array}{c}\text { KPI im- } \\
\text { plementa- } \\
\text { tion } \\
\text { Q1 }\end{array}$} & \multicolumn{2}{|c|}{$\begin{array}{l}\% \text { of the bo- } \\
\text { nus according } \\
\text { to the KPI } \\
\text { multiplier }\end{array}$} & \multicolumn{2}{|c|}{$\begin{array}{l}\text { Weight of the } \\
\text { indicator }\end{array}$} & \multirow{2}{*}{$\begin{array}{l}\% \text { of the due bonus } \\
5 \%\end{array}$} \\
\hline & & $25 \%$ & $x$ & $20 \%$ & $=$ & \\
\hline $\begin{array}{c}\text { Rotation of Finished } \\
\text { Goods }\end{array}$ & 50 days & $75 \%$ & $x$ & $20 \%$ & $=$ & $15 \%$ \\
\hline \multirow[t]{2}{*}{$\begin{array}{l}\text { Sales Profitability - } \\
\text { operating margin }\end{array}$} & $98 \%$ & $100 \%$ & $x$ & $60 \%$ & $=$ & $60 \%$ \\
\hline & & \multicolumn{4}{|c|}{ TOTAL $\%$ of the bonus } & $80 \%$ \\
\hline
\end{tabular}

Source: own research.

The table above shows the implementation of the Q1 indicator calculated per the number of days dependent on the rotation of semi-finished products, finished goods and sales profitability. That should be interpreted in accordance with the limits set and the assigned percentage level of bonus, appropriate for the implementation of KPI.

Table 2: Multiplier of the rotation of semi-finished products

\begin{tabular}{|c|c|}
\hline $\begin{array}{c}\text { KPI implementation } \\
\text { Q1 }\end{array}$ & \% of the due bonus \\
\hline$>78$ days & $0 \%$ \\
\hline$\leq 78 i>73$ days & $25 \%$ \\
\hline$\leq 73 i>65$ days & $50 \%$ \\
\hline$\leq 65 i>62$ days & $75 \%$ \\
\hline$\leq 62$ days & $100 \%$ \\
\hline
\end{tabular}

Source: own research.

As shown in Table 1, for 75 days of implementation of the Q1 index, in the case of semi-finished products, $25 \%$ of the bonus was awarded in accordance with the KPI multiplier. The obtained bonus share is to be successively multiplied by the weight of the indicator, appropriate for the rotation of aspecific ma- 
terial, in this case $20 \%$. The product of these two values gives the percent of the employee's due bonus. In turn the final result of the three components (shown in Table 1) obtained after conversion is the percentage of achievement of the total objectives. It is then used to calculate the premium fund, taking into account the EBIT and the percentage of discretionary bonuses.

The respondent states that KPIs are effectively calculated by the controlling department of the surveyed organization, and the calculated level of their implementation translates into the percentage of bonus received by employees, which is the result of the level of its effectiveness.

It is pertinent to note that the summary of the implementation of KPI objectives including all important aspects should take place during a conversation between the manager and the employee. Project teams after the implementation of the set goals within the KPI framework are supposed to participate in periodic meetings concerning the summary of previous activities, mutual cooperation, as well as the setting of further goals.

The managerial incentive system after each reporting period provides the management with information that enables the strategic review of the implementation of the given objectives. It also gives the possibility of calculating the main indicators which affect the further management of the company and its final results.

As the consultant points out, the organization under study uses reporting in accordance with the IBCS idea, which has a significant impact on the work efficiency of the controlling department.

\section{CONCLUSIONS}

In the era of the highly competitive environment in which today's enterprises function, it seems inevitable to improve processes, continuous development and effective motivation of subordinates.

Key Performance Indicators (KPIs) that are the subject of this work are of great importance in building the efficient and results-oriented organizational culture of the company. As a source of objective feedback on the work performed, KPIs affect positively the quality of performance of duties by employees and the level of their personal involvement. The controlling department, however, faces the challenges of proper supervising and documenting the objectives that determine the appropriateness of the relationship between the manager and the subordinates.

The paper analyzes the KPI on the example of the selected production and trading company in the Świętokrzyskie Province. The respondent has recognized that an application of the given methodology gives the organization knowledge that allows it to monitor the progress made towards achieving the set targets on 
an ongoing basis. This in turn allows to making quick decisions, assigning the appropriate priorities to activities and improving the company's development strategy.

The internalisation of attitudes and the motivation of employees to take productive actions are considered one of the most important benefits from the implementation of the KPI technique.

\section{REFERENCES}

Brown G.M., (1996), Keeping Score . Using the Right Metrics to Drive World Class Performance, Productivity Press, New York.

Kałużna J. (2016), Jak wyznaczyć cele i KPI dla kierowników działów?, „Controlling i Zarządzanie", $\mathrm{nr} 4$.

Szarska E. (2017), KPI- ryzyko dla zwinnych zespołów, „Controlling i Zarządzanie”, nr 5.

Grycuk A., (2010), Kluczowe wskaźniki efektywności (kpi) jako narzędzie doskonalenia efektywności operacyjnej firm produkcyjnych zorientowanych na lean, „Przegląd organizacji”, nr 2.

https://marketingwsieci.pl/slownik-e-marketingu/kpi/\# [01.03.2018].

http://www.leanpassion.pl/slownik/kaskadowanie-celow/ [02.03.2018].

$\mathrm{https}: / /$ www.investopedia.com/terms/k/kpi.asp [02.03.2018].

\section{KEY PERFORMANANCE INDICATOR JAKO WSKAŹNIK POMIARU EFEKTYWNOŚCI - ANALIZA WYBRANEGO PRZEDSIĘBIORSTWA}

Zarys treści:Key Performance Indicators stanowią istotny wskaźnik wykorzystywany przez organizacje $\mathrm{w}$ procesach pomiaru stopnia realizacji wyznaczonych celów. KPI pozytywnie wpływają na efektywność zadań wykonywanych przez pracowników, co determinuje poziom otrzymywanego przez nich wynagrodzenia. W artykule ukazano istotę i sposobność wdrożenia wskaźnika KPI oraz kluczowe wyzwania stojące przed działem controllingu. Przeprowadzone badania własne wykazały, iż zastosowanie analizowanej metodyki pozwoli na rozwój firmy i podejmowanie przez pracowników coraz to bardziej produktywnych zadań.

Słowa kluczowe:wskaźniki efektywności, motywowanie, controlling 
